DOI 10.37882/2223-2974.2020.09.15

\title{
ГОСУДАРСТВЕННЫЙ (МУНИЦИПАЛЬНЫЙ) КОНТРАКТ КАК ПРАВОВАЯ ФОРМА УДОВЛЕТВОРЕНИЯ ПУБЛИЧНЫХ НУЖД И СПЕЦИАЛЬНАЯ ДОГОВОРНАЯ КОНСТРУКЦИЯ
}

\section{STATE (MUNICIPAL) CONTRACT \\ AS A LEGAL FORM OF SATISFACTION \\ OF PUBLIC NEEDS AND SPECIAL CONTRACTUAL DESIGN}

\section{E. Matveeva}

Summary: In order to ensure state (municipal) needs, an agreement is concluded between the customer and the contractor, which is called a state (municipal) contract. The customer under such a contract can be municipal and state authorities, state (municipal) government agencies, state corporations, as well as all budgetary organizations receiving funding from the budgetary system. State (municipal) contracts differ from other civil contracts in their purpose. The main purpose of civil (municipal) contracts is to meet public needs. In the first part of the article, the author examines the features of state (municipal) contracts and the procedure for their conclusion. The second part of the article is devoted to the study of the phenomenon of the state (municipal) contract as a special contractual structure by means of which, in order to satisfy state and municipal needs, civil law contracts of various directions can be implemented.

Keywords: state (municipal) contract, customer, contractor, draft contract, civil law contracts, public needs, special contractual design.

\author{
Матвеева Елена Юрьевна, \\ к.ю.н, дочент, Финансовый университет при \\ Правительстве РФ \\ eyumatveeva@fa.ru
}

Аннотация: В целях обеспечения государственных (муниципальных) нужд заключается договор между заказчиком и исполнителем, который именуется государственным (муниципальным) контрактом. Заказчиком по такому контракту может выступать муниципальные и государственные органы власти, государственные (муниципальные) казенные учреждения, государственные корпорации, а также все бюджетные организации, получающие финансирование из бюджетной системы. Государственные (муниципальные) контракты отличаются от других гражданско-правовых договоров своей целью. Основной целью гражданских (муниципальных) контрактов является удовлетворение публичных нужд. В первой части статьи автор рассматривает особенности государственных (муниципальных) контрактов и порядок их заключения. Вторая часть статьи посвящена исследованию феномена государственного (муниципального) контракта как специальной договорной конструкции, посредством которой для удовлетворения государственных и муниципальных нужд могут быть реализованы гражданско-правовые договоры различной направленности.

Ключевые слова: государственный (муниципальный) контракт, заказчик, исполнитель, проект контракта, гражданско-правовые договора, публичные нужды, специальная договорная конструкция.

Государственные (муниципальные) контракты отличаются от других гражданско-правовых договоров своей целью. В обычных договорах контракт заключают с целью излечения прибыли либо с целью удовлетворения личных потребностей. В данном же случае основной целью гражданских (муниципальных) контрактов является удовлетворение публичных нужд - реализация различных программ, например, программа в сфере образования, здравоохранения. Имеют место также контракты государственного масштаба, реализующие обязательства Российской Федерации перед другими странами.

Все правовые отношения, касающиеся вышеуказанных контрактов, основаны на Конституции РФ, Гражданском и Бюджетном кодексе РФ.

Рассмотрим порядок и правила заключения государственного (муниципального) контракта.

Контракт может быть заключен только после подведение итогов проведенной закупочной процедуры. На 
данный момент времени все процедуры должны осуществляться только в электронной форме (ранее, до 1.03.2019 года, небольшие закупки, до 100 тыс. рублей, могли осуществляться без электронной процедуры). После проведения закупочной процедуры, в обязательном порядке должен быть определен победитель, о чем свидетельствует специальный подписанный протокол, только на основании этого протокола возможно заключение контракта. Если по каким-то причинам закупка не состоялась, в этом случае также подписывается отдельный протокол и закупка признается несостоявшейся.

У каждого контракта есть свои сроки для заключения. Сторона, которая не уложилась в сроки заключения контракта по тем или иным причинам может быть привлечена к ответственности, например для потенциальных исполнителей это может грозить включением в Реестр недобросовестных поставщиков. Принять участие в закупочных процедурах, тем самым стать поставщиком или исполнителем, может любой индивидуальный предприниматель или коммерческая организация, главное чтобы они отвечали требованиям заявленным заказчиком. В этом плане государственные (муниципальные) контакты не отличаются от других гражданско-правовых договоров.

На этапе объявления закупки государственным (муниципальным) заказчиком контракт уже должен быть составлен в виде незаполненного документа. Об этом сказано в статьях 50, 64, 73, 82.2, и других, в которых говорится об алгоритмах проведения закупочных процедур. Особенный алгоритм проведения закупочных процедур касается контрактов, осуществляющих обеспечение безопасности страны, поддержание обороны и правопорядка.

Как отмечалось выше, вначале должен быть разработан проект контракта, он разрабатывается еще на этапе подготовки документов к закупке. В проекте отображаются все основные условия, предусмотренные Гражданским кодексом РФ и ФЗ «О контрактной системе в сфере закупок». После того как разработан проект контракта и подготовлены все документы, обязательно их размещение в Единой информационной системе, далее проводится сама закупочная процедура, итогом которой становится заключение государственного (муниципального) контракта.

Общий порядок состоит из следующих частей:

1. Подготовка проекта;

2. Проведение закупочной процедуры;

3. Подписание протоколы, в котором указывается победитель (если участников было много) или единственный претендент, с которым подписывается договор. Если закупка не состоялась, протокол в этом случае также подписывается;
4. Если закупка состоялась, то на основании представленных исполнителем данных, заказчик заполняет до конца проект контракта;

5. На подписание контакта дается до пяти дней, после чего контракт либо подписывается, либо идет доработка разногласий (еще до трех дней). Если в ходе подписания возникли разногласия заказчик должен доработать проект контракта и снова направить его исполнителю;

6. В течение пяти дней с даты отправления исполнитель должен подписать контракт.

7. После подписания контракта исполнителем дается три дня для подписания его со стороны заказчика. После чего контракт считается заключенным.

Если начальная цена закупки (максимальная) не превышает один миллион рублей, контракт может не предусматривать обеспечения. Наличие обеспечения в этом случае зависит от воли заказчика. Под обеспечением в сфере закупок понимаются деньги, которые предоставляет исполнитель в виде залога финансовых средств или банковская гарантия. В тех случаях, когда начальная цена контракта выше одного миллиона обеспечение является обязательным и уже не зависит от воли заказчика, а предусматривается изначально при размещении закупки. Чтобы исключить возможные разногласия, обеспечение в контракте прописывается в отдельном разделе, с указанием, как и при каких условиях, обеспечение будет возвращено, а при каких условиях может быть удержано.

Государственный (муниципальный) контракт, заключенный для удовлетворения публичных нужд, должен быть в обязательном порядке выполнен в сроки, указанные в самом контракте или в приложении к нему. Исполнитель, подписывая контракт, тем самым дает свое согласие выполнить работу точно в срок и в полном объёме, предоставить товар надлежащего качества. Выполнение заявленных работ или услуг должно соответствовать стандартизационным документам, особенно это касается безопасности выполненных работ. Все перечисленные требования содержатся в описании контракта.

Государственный (муниципальный) заказчик в обязательном порядке должен обозначить в контракте, еще на этапе проекта, каким образом будет осуществляться приемка итоговых работ с указанием регламентирующих документов, на основании которых будет проверяться качество выполненных работ и услуг. Если исполнитель нарушает данные заявленные требования, он подвергается штрафным санкциям, которые установлены в Постановлении Правительства РФ № 1042, принятом в 2017 году. Однако и заказчик может быть оштрафован, вплоть до суда, если с его стороны будут нарушены какие-то взятые на себя обязательства. 
Государственные (муниципальные) контакты подразумевают бюджетное финансирование, в связи с этим, осуществляется казначейское сопровождение, целью которого является контроль за правомерным расходованием бюджетных средств.

Государственные (муниципальные) контракты, удовлетворяющие публичные нужды, являются довольно сложными и непростыми объектами гражданско-правового регулирования. Обусловлено это тем, что заказчиком является субъект, действующий в интересах всего региона или даже государства, не смотря на это, обе стороны контракта обладают равными правами и не предусматривает субординации и подчиненности по отношению к заказчику государственного (муниципального) контракта.

Вопрос правовой природы государственного (муниципального) контракта на протяжении многих лет оставался дискуссионным. Большинство авторов приходит к выводу, что данный правовой институт относится к специальным договорным конструкциям наряду с предварительным договором, договором в пользу третьего лица, публичным договором и т.д. Такое понимание государственного (муниципального) контракт основано на следующем юридическом признаке: «за госконтрактом всегда скрывается определенный гражданско-правовой договор»[15].

Квалификация государственных и муниципальных контрактов в качестве специальных договорных конструкций в достаточной степени обоснована многими учеными и автор статьи присоединяется к этому научному подходу.

Л.В. Андреева, оценивая содержание и правовую природу государственного контракта указывает, что «фактически государственные контракты можно заключать по модели любого договора в тех случаях, когда обеспечение государственных нужд предполагает применение договорного способа» [1]. И далее рассматривает государственный контракт как определенную юридическую конструкцию наряду с договором присоединения, предварительным договором, публичным договором, договором в пользу третьего лица, предусмотренными в Общей части ГК РФ. Интересно, что в данном направлении Л.В. Андреева рассуждала еще в 1997г., отмечая: «государственный контракт следует рассматривать как особый тип договора, стоящий в одном ряду с предварительным и публичным договорами, так как государственный контракт не имеет товарного характера» [2]. Таким образом, можно констатировать, что Л.В. Андреева является одним из первых ученых в отечественном праве, определившим государственный контракт как специальную юридическую конструкцию. Особого внимание данный факт заслуживает в связи с тем, что данный подхода был заявлен задолго до того, как концепция о специальных договорных конструкциях была озвучена В.В. Витрянским[4].

Демкина А.В. обозначает конструктивные особенности государственного контракта следующим образом: «Термин «государственный и муниципальный контракт» сохраняет свое юридическое значение как тип договора, включающий в себя договоры на поставку товаров, выполнение работ, оказание услуг и т.п., имеющий особенности в правовом регулировании, в связи с тем, что обязательной стороной в нем будет публично-правовое образование»[5]. А.А. Михайлова также отмечает универсальный характер государственных контрактов, полагая, что он имеет характер аналогичный характеру другой специальной договорной конструкции - конструкции публичного договора[8].

П.С. Тарабаев дает следующее определение: «Государственный контракт (публичный контракт) является универсальной гражданско-правовой (договорной) формой, опосредующей любые имущественные отношения, связанные с удовлетворением государственных нужд.» [12].

М.В. Шмелева также видит специфику государственного контракта в том, что «любой договор в системе гражданско-правовых договоров Гражданского кодекса РФ может обладать статусом государственного контракта» [13].

Пермяков Л.Е. считает, что «государственный контракт является особой договорной конструкцией, стороной которой является государство или публично-правовое образование» [9].

А.Е. Кирпичев в диссертационном исследовании «Муниципальный контракт в гражданском праве Российской Федерации выносит на защиту положение: «Муниципальный контракт, являясь основной формой участия муниципальных образований в имущественном обороте, представляет собой типовую конструкцию гражданско-правового договора» [7].

Имея, безусловно, свою специфику, обусловленную составом сторон, порядком заключения, изменения и расторжения данного договора, тем не менее, в зависимости от направленности, государственный (муниципальный) контракт в итоге в зависимости от предмета становится тем или иным гражданско-правовым договором. Так, согласно п.5 ст.454 ГК РФ поставка товаров для государственных нужд относится Гражданским кодексом к отдельным видам договора купли-продажи, согласно п.2 ст.702 ГК РФ подрядные работы для государственных нужд являются отдельным видом договора подряда, а, в соответствии с п.2 ст. 778 ГК РФ, государственные или 
муниципальные контракты на выполнение НИОКР, регулируются положениями главы 38 Гражданского кодекса, посвященной договорам на выполнение научно-исследовательских, опытно-конструкторских и технологических работ.

На основании того, что государственный (муниципальный) контракт является специальной договорной конструкцией опосредующей договорные отношения как поставки товаров, так и выполнения работ и оказания услуг для государственных нужд, ряд ученых обосновывают универсальность данного правового института по отношению к видовой классификации гражданско-правовых договоров, расположенных во второй части ГК РФ и считают необходимым дополнить подраздел «Общие положения о договоре» части первой ГК РФ статьей «Государственный или муниципальный контракт», закрепляющей легальную дефиницию государственного контракта и его конститутивные признаки $[6,10,11]$.

В статье дана общая характеристика государственного (муниципального) контракта как правовой формы удовлетворения публичных нужд. Обобщены взгляды цивилистов на правовую природу государственного контракта и его место в системе отечественного гражданского права.

Автор полностью солидарен с позицией Е.А. Цантурян, о том, что в теории гражданского права сформировался «новый подход к пониманию юридической сущности госконтракта, признанию его не самостоятельным видом (типом) гражданско-правового договора, а особой юридической конструкцией, направленной на опосредование отношений с публично-правовыми образованиями» [15].

\section{ЛИТЕРАТУРА}

1. Андреева Л.В. Закупки товаров для федеральных государственных нужд: правовое регулирование. М.: Волтерс Клувер, 2009. 296 с. - с.197

2. Андреева Л.В. Правовые проблемы обеспечения государственных нужд// Государство и право. - 1999. №8. - С. 29.

3. Белов В.Е. Поставка товаров, выполнение работ, оказание услуг для государственных нужд: правовое регулирование.- М.: Норма, 2011. - С.204.

4. Витрянский В.В. Специальные договорные конструкции в условиях реформирования гражданского законодательства.- Хозяйство и право. 2011 . №10. С. 3-17.

5. Демкина А.В. Государственные и муниципальные закупки: проблемы применения гражданско-правовых санкций: Монография / А.В. Демкина. М.: Норма; Инфра-М, 2012. 288 с.

6. Карасева, С.В. Правовое регулирование размещения государственного заказа и исполнения договора на оказание услуг для государственных, муниципальных нужд : дис. ... канд. юрид. наук : 12.00.03. - М., 2013.- 193 с.- с.35, с.36.

7. ирпичев, А.Е. Муниципальный контракт в гражданском праве Российской Федерации : дис. ... канд. юрид. наук: 12.00.03. - М., 2011. - 167 с.- с.9.

8. Михайлова А.А. Подрядные работы для государственных нужд: особенности правового регулирования: автореф. дис. канд. юрид. наук : 12.00 .03 - СПб., 2005. - c.16.

9. Пермяков Л.Е. Правовое регулирование поставки для государственных нужд: Автореферат диссертации на соискание ученой степени кандидата юридических наук/ М., 2006. 30 с.;

10. Рахимов Э.Х. Гражданско-правовое регулирование государственного заказа в деятельности органов внутренних дел: дис. ... канд. юрид. наук. 12.00 .03$. - СПб., 2010. - С.10.

11. Степанова Е.Е. Контрактная система в сфере закупок: опыт цивилистического исследования: Монография. СПб.: Гамма, 2018. 228 с.

12. Тарабаев, П.С. Гражданско-правовое регулирование поставки товаров для федеральных государственных нужд : дис. .... канд. юрид. наук: 12.00.03.- Екатеринбург, 2008. - с.9.

13. Шмелева, М.В. Гражданско-правовое регулирование контрактных отношений при государственных и муниципальных закупках в Российской Федерации : дис. ... канд. юрид. наук : 12.00.03. - Саратов, 2013.- - с.18.

14. Цатурян, Е.А. Государственный контракт как специальная договорная конструкция //Законодательство. -2013. - № 11. - С. 13

15. Цатурян, Е.А. Государственный контракт в гражданском праве России: проблемы теории и практики: монография. Москва: Статут, 2020.224 с. 